\title{
Imagining the Periphery: The Construction of Orientalist Discourse in Turkish Airlines Advertisements
}

\author{
Ar. Gör. Dr. Alparslan NAS
}

marmara üniversitesi iletişim fakültesi reklamcılık ve tanıtım anabilim dalı alparslan.nas@marmara.edu.tr

\begin{abstract}
Critical studies on Orientalism interrogates the hierarchies of power constructed between the East and the West. It has been stated that orientalist discourse has been instrumentalized by the West as a vehicle to sustain hegemony over the East. Approaching the notion of Orientalism from a national perspective, this article aims to critically analyze the manifestation of Turkey's center-perphery relations in the advertising discourse. For this purpose, this article undertakes a critical discourse analysis of two Turkish Airlines advertisements about the opening of Iğdır and Ordu-Giresun Airports in Turkey's peripheral provinces. Accompanied by the discourses of nationalist and consumerist ideologies, this article argues that advertisements constitue an orientalist discourse that situates the peripheral other vis-à-vis the Western self, represented by the technological, modern, developed and civilizational values of Turkish Airlines.
\end{abstract}

keywords: orientalism, Turkey, east, west, advertising, discourse 


\section{Résumé}

\section{Imaginer La Province : La construction du discours orientaliste dans les publicités de Turkish Airlines}

Les Études critiques sur le concept de l'orientalisme ouvrent la voie au questionnement sur les relations hiérarchique entre les civilisations orientale et occidentale. II a été montré que le discours orientaliste fonctionna comme un outil de l'Occident pour établir l'autorité sur L'Orient et les relations de domination existantes commencèrent par être regardées de manière critique. Cette étude considérant le concept d'orientalisme avec une perspective locale, a l'intention d'examiner de façon critique les relations centre/province en Turquie dans l'expression du discours de la publicité. Dans ce contexte, les deux publicités différentes de Turkish Airlines, qui mentionnent l'inauguration des aéroports d'lgdir et Ordu-Giresun, ont été ici analysées pour démontrer qu'un discours orientaliste a été construit dans ces publicités. Cette étude, qui analyse les publicités dans les méthodes du discours critique, est destiné à montrer que le discours qui est créé positionne l'orient comme une province, l'occident au centre et cela dans un rapport hiérarchique du pouvoir orientaliste.

mots-clés: I'orientalisme, Turquie, l'ouest, l'est, publicité, discours

\section{Öz}

\section{Taşrayı Hayal Etmek: Türk Hava Yolları Reklamlarında Şarkiyatçı Söylemin İnşası}

Şarkiyatçııı (Orientalism) kavramına yönelik eleştirel çalışmalar, Doğu ve Batı medeniyetleri arasındaki hiyerarşik güç ilişkilerinin sorgulanmasına zemin hazırlamıştır. Şarkiyatçı söylemin, Batı'nın Doğu üzerinde bir iktidar kurma aracı olarak işlevsel kılındığı belirtilmiş ve mevcut egemenlik ilişkileri eleştirel açılardan ele alınmıştır. Bu çalışma, şarkiyatçılık kavramını yerel bir bakış açısıyla ele alarak, Türkiye'de merkez-taşra (center-periphery) ilişkilerinin reklam söylemindeki dışavurumunu eleştirel olarak incelemeyi amaçlamaktadır. Bu bağlamda, Türk Hava Yolları'nın Iğdır ve Ordu-Giresun Havaalanları açıışlarını konu eden iki farklı reklamını çözümleyen bu çalışma, reklamda şarkiyatçı bir söylemin inşa edildiğini iddia etmektedir. Eleştirel söylem analizi yöntemiyle reklamları analiz eden bu çalışma, inşa edilen söylemin bir taşra olarak Doğu'yu, bir merkez olarak Batı karşısında şarkiyatçı bir iktidar hiyerarşisi dahilinde konumlandırdığını göstermeyi hedeflemektedir.

anahtar kelimeler: şarkiyatçılık, Türkiye, doğu, batı, reklam, söylem 


\section{Introduction}

The notions of the "East" and the "West" have pointed at a dichotomy between civilizations that has culturally and politically been established throughout centuries up until today. The streams of globalization that accelerated since the $19^{\text {th }}$ century paved the way for the emergence of cross-cultural encounters more often than the past. Parallel to the currents of globalization, development of communication technologies and the rapid spread of the means of mass communication provided an increased activity and visibility to the cross-cultural interactions globally. As an outcome of such developments, the boundaries between the East and the West has been continuously negotiated, altered, overcome or reestablished with new definitions, perceptions and varying audiences. The juxtaposition of the East and the West in cultural, political and economic respects within different eras and settings has pointed out the dynamic nature of this dichotomy. The distinction that relies on the East and the West has been a definitive agent in determining one's relation to the other that has culturally and politically been established.

The distinction between the East and the West as a concomitant process of othering and self-representation has been one of the prominent points of debate within the studies on colonial era, that crucially marked the distinction between the two geographical spaces. Emerged as the critique of Orientalism most importantly in the works by Edward Said, the critical stance put forward the hierarchies of power established between two distinct geographical settings, namely the East and the West. The West, as mainly characterized as European countries and the United States has historically been positioned in opposition to the East that has occasionally been located as Middle East and Far East. The scholarship and artistic works on the East conducted by the Western academics, writers and artists since the late Middle Ages constituted a huge body of representations, that established a discourse of the East not only in geographical terms but also and most importantly in cultural and political aspects. The critique of Orientalism therefore suggested that the continuous attempt held by the West to represent the East in visual and discursive ways was indeed a means of power relations that aimed to dominate the East as the inferior other. The literature on post-colonialism therefore aimed at a deconstruction of texts and visual materials in Western civilization that discursively established and constituted the East in order to expose the power relations ingrained in the representations of the Orient.

In contemporary society characterized with the advent of consumerism and globalization with increased networks of communication, the term Orientalism and its critique continues to remain as an analytical tool to critically probe the boundaries between the self and the other. The media, with its traditional and new formats, contributes to the circulation of culturally constructed meanings 
to a variety of audiences on national and global levels, which plays an important role in the reestablishment of the boundaries between the East and the West, the Orient and the Occident, the self and the other. Advertising, in this regard, is an important cultural mediator that semiotically and discursively establishes certain representations incorporated with the imagery of the self and the other in cross-cultural terms. The market's interest in expanding its consumer segments to different cultural groups on national and global levels marks the increasing role of advertising as a tool of communication that circulates culturally established meanings across societies. Critically elaborated as a medium of representation that is capable of disseminating ideologically encoded meanings by constructing subjective forms of reality rather than merely communicating the reality as it is, advertising is also a crucial medium that mediates between the East and the West by constituting certain representations and discourses on the East. Hence the images and the discourses portrayed by advertising provide a vast array of representations that can critically be analyzed in order to expose the hegemonic meanings attributed to the East.

Basing its theoretical arguments on Said's (1978) critique of Orientalism with reference to media representations particularly to advertising discourse, this paper critically interrogates the representations of the East in advertisements by Turkish Airlines, national flag carrier airline of Turkey. Founded at 1933 in the name of State Airlines Administration, Turkish Airlines went through an extended technological development throughout $20^{\text {th }}$ century, as it became a global brand today as one of the leading airline companies, ranking fourth according to the World's Top 100 Airlines in 2015.1 Aiming at a global investment, the company makes use of Istanbul as a main hub connecting the East and the West to each other, claiming to be flying to most destinations with the slogan "widen your world". While the company's brand image in the world promotes a global image with the use of celebrities in advertisements such as Lionel Messi and Kobe Bryant, its national advertisements include representations of the Eastern part of Turkey, which forefronts local aspects. Particularly, two advertisements regarding the opening of two different airports at Iğdır and Ordu-Giresun, Turkey's Eastern provinces, and the launching of the flights to these destinations involve representations of the East, which opposes itself to Turkey's West as a more technological, developed and civilized setting. Undertaking a critical discourse analysis of the advertisements, this paper argues that the orientalist dichotomy between the East the West has been rearticulated by Turkish Airlines and applied to the relations between Turkey's West as the country's founding, privileged "center" and its East as the "periphery", underdeveloped, less civilized other. The critical analysis shows that Turkish Airlines advertisements imagine Turkey's periphery in an orientalist vision by reproducing generalized and stereotyped definitions on the peripheral other, while concomitantly opposing it

1 Skytrax World Airlines Awards are listed as follows: http://www.worldairlineawards.com/awards/ world_airline_rating.html 
to the Western self at Turkey's center, emphasizing its superiority in technology and civilization.

\section{Orientalism: A Theoretical Overview}

Historically, Orientalism refers to the artistic, literary and academic works and researches on Eastern societies named the "Orient" since the late $15^{\text {th }}$ century. The notion is also employed to define the artistic movement in the $19^{\text {th }}$ century where Orientalist Art was widely practiced by Western artists. In this period, political developments in Near, Middle and Far East particularly imbued with the interactions between the colonizer Western countries and the colonized Eastern societies paved the way for cultural encounters that were systematically depicted in literary and artistic works in the West. The East therefore became an object of study and attraction, which aimed to somehow define, make known and classify the peoples of the Orient (Burke and Prochaska, 2007, p. 139). The endeavor to define the East has further been institutionalized with academic and scholarly organizations, which paved the way for the East to be studied as "a career" (Said, 1978, p. 5). The increasing Western interest on the Orient by the $19^{\text {th }}$ century brought along the problematic of representation and power, where the Western individual was considered as the viewer and the observer of the Eastern subject in the fields of art, literature and academia. Eventually, Orientalism was an attempt to speak on the Orient and for the Orient, rather than letting the Orient speak for itself.

The asymmetrical relationship between the West and other societies all around the globe was critically interrogated by $20^{\text {th }}$ century scholarship under postcolonial studies with the advent of the uprisings against colonial domination in Asia and Africa, together with the gradual collapse of the colonial era. In this regard, Frantz Fanon (1963) supported the decolonization movements, particularly the Algerian War of Independence against France, claiming that the ideology of colonialism aimed to dehumanize individuals by an absolute subjugation. In one of his other writings on the revolutionary potential of the colonized, Fanon (1964) called for an African revolution to emancipate the continent from the colonial domination, by basing his arguments on a psychiatric point of view regarding the destructive aspect of colonialism. In addition to scholarly interventions, literary works also pointed at the negative impact on colonialism on colonized societies. In his novel Things Fall Apart, Nigerian writer Chinua Achebe (1994) narrated the colonial experience of Nigerian society under the cultural hegemony of British Empire, and the national struggle to claim back the Nigerian identity by the resistance for decolonization. The aims for decolonization and its possibility against the colonial dominance was also stressed by Spivak (1988), who formulated that the subaltern societies subjugated by the colonizers are deprived of any means to speak for themselves for full emancipation. According to Spivak, the subaltern, namely the oppressed social groups under the colonial rule, was subjected to the Foucauldian notion of "epistemic violence", which 
suggests that they are deprived of the necessary means to recreate themselves since their existences are already defined and imposed on them by the dominant Western ideology (1988, p. 281). In this respect, the aim of postcolonial studies was to expose the relations of domination by pointing at the ways in which the East, in other words, the subaltern or the oppressed is textually, verbally or visually represented by the West to ensure the continuation of the relations of power and hegemony.

Researches on postcolonial condition entered into a new critical phase after Said's critique of Orientalism (1978). Extending Fanon's understanding of Western dominance as a dehumanizing factor, which points at the process of objectification of the oppressed, Said (1978) draws attention to the processes in which the oppressed is subjectified with discursive mechanisms, which in turn triggers a mechanism of internalization of inferiority vis-à-vis the dominating West. Accordingly, Said contends that rather than a means of repression and coercion, Orientalism activates a cultural hegemonic formation based on the superiority of the West contrary to the inferiority of the East, which is internalized by both agents of the Oriental divide (1978, p. 7). With reference to Foucault's notions of discourse and power (1978; 1995), Said suggests that Orientalism should be considered as a discourse that is systematically established by European culture "to manage and produce the Orient politically, sociologically, militarily, ideologically, scientifically and imaginatively during the post-Enlightenment period" (1978, p. 3). In this sense, the orientalist conception of the East and its comparison with the West points out an epistemological and an ontological distinction between the Orient and the Occident, which becomes instrumental in reproducing the "consent" of both agents (Said, 1978, p. 7). In addition to his reference on Foucault, Said further cites Gramscian (1971) terminology of "cultural hegemony" in order to underscore the ways in which Orientalism serves as a system of thought that delineates Western superiority over the East by at the same time generating the consent of the oppressed (1978, p. 7). Said's conceptualization of Orientalism shows that the West dominates the East by continuously establishing and reproducing it as a hegemonic discourse which is also internalized by the Oriental subject. In this regard, Said (1997) notices that media is an important apparatus for the reproduction of orientalist discourses since it "covers" the other in two opposite meanings: The media covers the other by making news about it; however, by providing it with a visibility, it also hides the truth about the other by constructing its own version of reality. Eventually, the element of representation becomes a crucial factor in orientalist vision as representation provides a useful medium for Orientalism to manifest and reassert binary oppositions between the Orient and the Occident. The West, in this regard is represented as developed, powerful, rational and superior whereas the East is represented as undeveloped, weak, emotional, mysterious and inferior (Kim and Chung, 2005, p. 73). Orientalism further entails a patriarchal narrative, which attributes the West with masculine tendencies while it feminizes the East and turns it into an object of desire for the superior, 
Western male gaze (Kim and Chung, 2005; Owens, 2010). As a sophisticated form of stereotyping propelled by the networks of power (Madood, 2005, p. 59), Orientalism continues to remain as a powerful tool in the media representations, including advertising imagery (Kim and Chung, 2005; Lin, 2008). Intersecting with gendered, ethnic, classed or militarized narratives, advertising discourse makes use of the orientalist formula to represent the Orient in marketing of goods and services to the consumer segments culturally located in the East, continuously reproducing the stereotyped images of the other.

\section{Orientalism in Turkish Context}

The Turkish experience provides a unique setting to observe the historical development of orientalist dynamics. Turkey and its processor, the Ottoman Empire holds an exceptional stance in terms of colonial dynamics in the sense that the country was neither colonized nor colonizer (Erol, 2015, p. 1; Wright, 2005 , p. 144). Despite its unique status in terms of cross-cultural colonial relationship, Turkey historically involves mechanisms of internal Orientalism and colonialism since the foundation of the Turkish nation-state at 1923, especially in the early period of the nation-state when minority groups including Kurds and non-Muslim populations were targeted with systematic acts of cultural, economic and political discrimination (Zeydanlıoğlu, 2008). The newly founded Turkish nation-state facilitated Turkification policies against non-Turkish and nonMuslim groups, which also aimed at "modernizing" these groups by establishing a hierarchy between Turks and non-Turks suggesting that non-Turks are less modernized, more vulgar and should be Turkified for their survival (Aktar, 2008). During this era, the hegemonic relationship established between the founding elite and the remaining populations of the nation-state paved the way for the newly settled power hierarchies, conceptualized by Şerif Mardin (1973) with reference to the theoretical framework of "center-periphery relations". According to Mardin, the political and cultural landscape in Turkey, including the tensions and conflicts it unfolds, can be best understood in terms of the power hierarchies between Turkey's center and periphery (1973, p. 169), rather than the notion of class in a Marxist sense of the term. Historicizing the impact of the center since the late Ottoman Empire to the mid-20th century Turkey, Mardin asserts that the bureaucratic elite located at the center, namely the main political and industrial agents at urban hubs of the country such like Istanbul and Ankara, also acted as driving agents in other areas of social life, not allowing the agents of the periphery to penetrate into main economic and political circles (1973, p. 183). Led by the influence of the single-party rule of Republican People's Party since the foundation of the Turkish Republic, Mardin further notices that this hegemonic relationship was occasionally challenged after Turkey's entrance to multi-party era after 1946, when Democrat Party, representative of the peripheral regions of Turkey, won consecutive elections between 1950 and 1960 (1973, p. 184). Since then, Turkey's political and cultural landscape have been deeply affected by the tension between the center and the periphery, 
where the republican modern elite with a Western outlook encounters with the peripheral subject, which is more or less associated with more traditional, less developed, economically underdeveloped, Islamic or non-Turkish belongings.

The conflict between the center and the periphery has also been subject to various representations in Turkey's visual culture including cartoons, films and television since the 1960s. Mostly inspired by the mass flows of migration from peripheral regions to industrial urban centers for work opportunities, famous cartoon figures such as "Hacıağa" and "Maganda" illustrated the peripheral individual as vulgar and barbaric, not fully integrated to the urban lifestyle and constantly failing to modernize himself/herself (Öncü, 1999). Especially in the post-1980 coup d'état period when the flows of migration to urban industrial hubs reached its peak, Gürbilek (1992) observes that the center had to encounter the periphery that it tended to avoid since the establishment of the nation-state, defining the process with reference to Freud's "return of the repressed." For Gürbilek (1992) the 1980s marks a depoliticized post-coup d'état era where the sphere of culture gained increasing prominence with the foregrounded themes of sexuality and the "arabesk" music as the periphery's sound in the urban space. With movies and songs, the arabesk in this period turned the peripheral experiences of discrimination into a commodity of the culture industry (Stokes, 1993), involving various representations of the peripheral other that encounters and conflicts the center, either defeating or being defeated by the modernized urban self. Such representations in popular culture reproduced the hegemonic relationship between the center and the periphery, legitimizing an orientalist formula characterized by the superiority of the center vis-à-vis the inferiority of the periphery in Turkey's contemporary cultural landscape.

Despite several scholarly works critically negotiating the field of visual culture with regard to the popular representations of the center and the peripheral relations in Turkey particularly from an orientalist framework, the field of advertising has largely been unexplored. It has been discussed that advertising discourse in Turkey promotes a distinct kind of self-orientalism, as it tends to represent its cultural sphere in accordance with Western definitions imposed on and internalized by Turkish culture (Nas, 2013). Internalization of the Western gaze that imagines the Orient and transferring of that imagination to the subjectivities of the Oriental other constitutes an important aspect of orientalist power dynamics. With advertising, such internalization gains a market-related dimension, where orientalist Western gaze becomes an apparatus for advertisers to approach consumers whose identities are perceived as non-Western or peripheral. In this sense, advertising itself becomes a vehicle of colonization, in other words by Williamson, advertising is characterized by "capitalism's constant search for new areas to colonize" (Williamson, 1986, p. 116). The Oriental other, that is, the other that the powerful self imagines and discursively establishes from a central position, becomes an object of advertising discourse to stimulate consumption (Kim and Chung, 2005, p. 77). In this respect, the Oriental other, 
that the discourse of advertising targets, may include lesbians (Clark, 1991), women (Cagan, 1978), minorities (Cortese, 1999) and other ethnic or religious groups (Lin, 2008). Seemingly promoting a narrative of multiculturalism and the celebration of difference, the contemporary advertising discourse actually instrumentalizes the existing definitions on the self and the other with an orientalist vision to reach out new consumers and therefore commodifies both Orientalism and multiculturalism (Kim and Chung, 2005, p. 77). The way advertising acquires Orientalism in the transnational circulation of goods and services necessitates the reconceptualization of the critique of Orientalism under globalization (Mudambi, 2013, p. 279). With the rapid expansion of markets and the flows of subjectivities all around the globe, the global community is made of differentiated identities that require the newly articulated definitions of the colonizer and the colonized, the Orient and the Occident, the self and the other (Appadurai, 1996). Therefore, the relations between the center and the periphery in Turkey and their articulation by the contemporary discourse of advertising put forward the local dynamics of the Oriental dichotomy between the self and the other, in other words between Turkey's industrial, technological, global center and its rural, underdeveloped, local periphery, as represented by Turkish airlines advertisements.

\section{Note on Methodology}

The main problematic of this research is to point out the ways in which advertisements play a role in establishing or reproducing orientalist discourses in Turkish cultural context. In order to explore such phenomena, Turkish Airlines brand is preferred as an object of critical analysis since it is the leading airlines brand and the national flag carrier of Turkey. The status of Turkish Airlines with a national significance is thought to provide useful insights regarding the ways in which the nation is perceived and narrated by this brand. Furthermore, considering the brand's positioning of itself as a national brand with global -particularly Western-emphasis is thought to be reflected on its advertisements. Therefore, this research aims to explore the problematic of Orientalist representation in advertisements to point out the ways in which a global and Western-positioned brand discursively establishes the nation and particularly the Oriental subject. In order to critically negotiate the West vs. East dichotomy as narrativized by the brand, this research undertakes the analysis of two advertisements; Hayal Edince (When Imagined) and Vazgeçme (Do not give up) broadcast respectively in April 2014 and in June 2015. The sample of this research has been limited to these two advertisements since these are the two advertisements broadcast by the brand specifically declaring the opening of two peripheral airports. The broadcasting of these advertisements dedicated to the airport opening occasions shows that the brand pays special importance to these events and aims to strengthen its brand image by communicating certain messages to nation-wide audiences. This research accordingly aims to discover the discursive patterns of the kinds of messages that is being conveyed, particularly with regard to orientalism. For this 
aim, the research has been designated as a discourse analysis; since the analysis of the advertisements is considered to provide insightful knowledge regarding the ways in which the periphery is imagined and discursively established by the brand as the Oriental other.

The critical analysis of advertisements constitutes the major part of this research's methodology. In the existing literature, the research of advertisements from a critical perspective focused on exposing power relations and hegemonic meaning structures that are established and reproduced by the advertising discourse in gendered, classed and racialized formats (Goffman, 1976; Goldman 1992; Jhally 1990; McFall 2004; Williamson 1978). Rather than merely serving as a medium of representation, it has been argued that advertising is an important element of capitalist superstructure that is capable of reproducing the narratives of power, hegemony and ideology by naturalizing and legitimizing various forms of domination (Gill, 2009; Fowles, 1996; Leiss et al., 1990; Williams, 1999). Proceeding from the Turkish experience of the Oriental dichotomy that is manifest in the relations between the center and the periphery, this article analyzes two advertisements by Turkish Airlines with a critical discourse analysis. Mainly concerned with the textual and visual strategies by which power and discourse is established in a certain context, critical discourse analysis treats narratives as cultural artifacts that legitimizes and naturalizes relations of power, as it seeks to uncover those relations to expose how power operates on the level of discourse (van Dijk, 2001, p. 363). A critical discourse analysis will point out the ways in which Turkish Airlines advertisements inhabit the relations of power on a discursive level that maintains the hierarchies between Turkey's center and the periphery in an orientalist vision.

Turkish Airlines is the national flag carrier airline of Turkey and ranks among the best airlines in the world. The state-sponsored company was founded at 1933 and it was not until $21^{\text {st }}$ century when Turkish Airlines took bold steps towards being a global corporate brand as it became the largest carrier worldwide flying to 108 countries (Turkish Airlines, 2014, p. 1). With 284 destinations, Turkish Airlines is the $4^{\text {th }}$ largest airline in terms of the flying network globally and ranks $7^{\text {th }}$ in terms of the number of passengers which exceeded to 32 million in 2014. The company aimed to increase its brand awareness with advertising campaigns including global celebrities such as football players Lionel Messi and Didier Drogba, and basketball player Kobe Bryant, especially in the recent years (Turkish Airlines, 2014, pp. 20-21). According to the annual financial report, the company spent 370.079.692 Turkish Liras on advertising in 2014, whereas the number is 252.395.319 Turkish liras in 2013 (Turkish Airlines, 2014, p. 142). In addition to the endeavor on global recognition of the brand, Turkish Airlines also broadcast advertising campaigns in the last two years for its brand awareness on national level. Other than commercials on sales and promotion offers, the company broadcast two advertisements that highly rely on cultural narratives. The first advertisement was broadcast on TV and online in April 2014, entitled 
Hayal Edince (When Imagined). The advertisement narrates the story of children in Iğdır, Turkey's one of peripheral provinces, who wait for the opening of an airport for long years and celebrate the opening with at the same time Turkish Airlines plane boarding. Upon its broadcast, the advertisement provoked an emotional outburst as the children starring were hosted on several national TV programs most popularly on Beyaz Show, one of the most popular talk-show programs on television. Children's appearance on TV as children living in the periphery marked the encounter of the urban middle-class hegemonic gaze with the other, namely, the peripheral, Oriental subject. The second advertisement, Vazgeçme (Do not give up) was broadcast in June 2015, narrating the first plane travel of a children's football club to Istanbul from Giresun and Ordu, Turkey's peripheral provinces in the Black Sea Region. Similar to the first advertisement, the discourse relies on the technological and civilizational enlightenment that the peripheral subject goes through in Turkey's two provinces where it meets with the services of airports and airplanes for the first time. Bearing on the hierarchies between the superior gaze of the center and the inferior positionality of the periphery, the advertisements reproduce the dominant relations of power by rearticulating a narrative of Orientalism comprising of the representation of the self and its distinction with the other. Following Saidian theoretical framework, which suggests that Orientalism promotes "imaginative geographies" (Said, 1978, p. 49) rather than representing a particular geography as it is, advertisements illustrate the ways in which the periphery is imagined by Turkey's westernized, developed, technological self as represented by Turkish Airlines advertisements.

\section{Analysis of Advertisements}

\section{Narrative 1: "When Imagined"}

The advertisement When Imagined ${ }^{2}$ begins by portraying vast plains lying below a hill where four children, three male and one female, are sitting and looking towards the plains. Children wear villager clothes that are old-fashioned and are encoded as "non-modern". One of the children sees a plane flying high over the plains and points it with his hand, following its movement by moving his right hand towards the flying direction. In seconds, the camera shows the settlement on the plains which is a small village consisting only of tens of houses where the children live. As an emotional music enters, the boy pointing at the plane asks, speaking in a local accent: "Do you think that the plane goes to Istanbul?" The girl responds: "Yes, where would it go other than Istanbul?" The girl holds her head in her hands and responds to the boy in a disappointing manner, as if she is longing for the plane. Another boy responds desperately: "Surely it won't come here in any way." The boy, who was pointing his finger towards the plane in the first scene, replies: "If we want it so much, it can come

2 "When Imagined" advertisement was also published online in the following link: https://www. youtube.com/watch?v=oSDOYigRW3o 
here as well." In the following scene, the children walk down the hill to the plains to set up an experiment. Seen next to houses that are made of irregularly compounded stones with lack of infrastructure, the children are portrayed as running and playing in a joyous character. A flock of sheep and horses are seen in the background, asserting the village like environment with its non-industrial mode of production. In the following scenes, the children are portrayed as getting prepared to employ their plans by gathering pieces of stones, painting the grounds with white bold lines, constructing a tower-like structure by putting a table upside down onto a fountain and decorating it with a Turkish flag. The scene finally portrays the children's plans in total; they constructed a simulation of an airport and self-declared it as "Iğdır Airport" by writing the name with stones on the airport runway. The children then wait for a plane, as one of the boys see one flying above, they all get excited, stand up, call for the plane to land by waving their hands yelling: "Here, look at here!" The plane however goes and children are left in despair. The scene is followed by another one, which portrays children continuing to wait for the plane at night, in the middle of a wedding ceremony where people celebrate with traditional music and wearing. Inspired by the array of lights used to enlighten the wedding ceremony, children use the lights to be able to attract attention of the airplane passing by very early in the morning. Left in despair once again, children are disappointed by diminishing of their hopes, saying to each other "it doesn't come". In just a few seconds, the boy standing on the tower-like structure notices an airplane appearing between the hills and descending. Children get surprised, provokingly happy, getting prepared to welcome the plane. The scene then shows the plane landing on the runway made by children. The boy, standing on the tower, makes a salute toward the plane like a soldier. Running in joy, the children go after the plane, climb up a small hill in a few seconds and see that the plane is landing on the airport runway, that is, the newly constructed airport in Iğdır. With four children looking towards the plane while landing, Mount Ararat is also seen in the middle, rising enormously miles away from the airport. In the final scene, the plane lands as the staff and passengers exit the plane with local people are waiting them with flags in their hands. Held almost like a national ceremony by the locals, the children appear in the crowd, also waiting for the staff to walk through. A good-looking male pilot appears on the scene, recognizes the children waiting, approaches them and salutes them while passing by. Children smile back and the narrator begins as the advertisement ends: "It is no good to fly the most destinations in the world if there is one single place left in Turkey that we don't fly."

The advertisement involves crucial remarks in terms of the establishment of a discourse of Orientalism. Entitled "when you imagine", the advertisement is a narrative of how the Occident imagines the Orient in certain respects. The advertising discourse represents the East with four children characters, who are demandingly and passionately waiting for the plane to arrive at their village. This basic element of the narrative is the first mechanism that establishes a power hierarchy between the center and the periphery; the center is portrayed as 
technological and active whereas the periphery is encoded as underdeveloped and passive. The particular dichotomy between the Orient and the Occident is designated in such a way, which characterizes the peripheral, Oriental subject as if waiting for being rescued by Western superiority in technological and civilizational advancement. The use of children in this regard constitutes another element of the orientalist discourse, that is, the peripheral East is positioned in a childish character with weaknesses, not fully be able to actualize itself and not yet fully developed; while the central West is represented with signifiers that are mature, developed, determined and advanced. The advertisement is filled with certain discursive elements that continuously tend to encode the inferiority of the Oriental subject; the children are speaking in local accents that is very different from the nationally recognized accent of Turkish language, wearing traditional clothes that are partially dirty, portrayed not as separate individuals but as collective beings celebrating weddings with traditional songs in masses and living under poor conditions of housing and infrastructure. Such discursive strategies however are not employed as apparatuses that explicitly otherize and insult the East; contrarily the discourse turns the Oriental subject into an exotic being presented to the superior Western gaze so that he/she can hegemonically engage in an act of viewing the East with pleasure. This way of viewing the East also entails a hegemonic way of seeing since the narrative implicitly conveys the discourse of power relations which locate the Oriental subject as underdeveloped, uneducated, not being able to actualize itself as an individual and submissive to Western superiority.

The dimension of submissiveness is boldly manifest in the boy's saluting the Turkish Airline plane like a soldier; it is the point where the ideology of militarism accompanies the orientalist narrative. The boy saluting the plane as if he is a soldier actualizes two things on discursive level; first, it explicitly performs the hierarchy of power between Western superiority and Eastern inferiority, as it is the East that salutes the West as if an authority figure is passing by. The boy saluting the authority figure is a representation which shows that Oriental subject as being interpellated in Althusserian terms (2012) by the dominant ideology of the Turkish nation. Furthermore, the advertisement conceals the real power dynamics behind the representation of the boy saluting the soldier, that is, the Kurdish conflict in the area and the armed struggle lasting more than 30 years. The figure of the plane is supposed to be a frightening figure for children since thousands of villages have been destroyed and the residents were subjected to forced migration especially during the 1990s as a result of the armed clashes between the Turkish army and Kurdish forces. Therefore, contrary to what advertising discourse manifests, the figure of the plane may well be an apparatus of oppression and trauma for the children of the region, an aspect, which the advertising discourse systematically conceals. Contrarily, the scene marks the happening that the boy is provided with subjectivity by the hegemonic establishment; he becomes an ideal subject of the nation who will serve to the army as a courageous soldier in the future. Furthermore, the 
act of saluting that introduces a narrative of militarism also intersects with the discourses of hegemonic masculinity since the military service is culturally encoded as a masculine performance in Turkey. Accordingly, the boy saluting not only performs his belonging to the nation, but also performs his gendered expectations arising from the hegemonic masculinity imposed on him by the supreme ideology of the nation. ${ }^{3}$ As the plane lands in the final scene, the children encounter the "white", strong, good-looking man as the pilot figure, who salutes back the boy in an authoritative and confident manner. At this point, the advertising discourse actualizes the particular encounter between the center and the periphery; the marketing attempt of Turkish Airlines turns into a narrative of nationalism and militarism that intersects with the discursive strategies of Orientalism. In terms of the marketing point of view, the advertisement attempts to reach out to different markets and expand its scope of operation to the newer markets such as a provincial setting in Turkey. In doing so, the discourse of the advertisement however sets up a narrative of power relations that subjugates the peripheral subject. In sum, what the advertisement does is to turn the Oriental individual into a subject of the national ideology driven by the superior positionality of center, by at the same time turning it into a potential consumer in the market.

\section{Narrative 2: "Do not Give Up"}

The second Turkish Airlines advertisement was broadcast on TV in June 2015 with the title Do not Give Up. ${ }^{4}$ Similar to the first advertisement, the narrative represents the experiences of a group of children in Giresun and Ordu, two neighboring cities in Black Sea region, with regard to the opening of OrduGiresun Airport. The advertisement begins with a birds-eye view of green plains, where a football pitch is located at the center. A group of male children are playing football as a middle-aged male coach trains them. During the training session, a man appears from distance and yells towards the training ground: "I have good news! We are going to the finals with plane!" One of the boys gets anxious and says: "With plane? How come!" Another boy in the training ground asks him mockingly: "Are you frightened?" The boy reacts in anger and replies: "Why would I get frightened? Am I a child? I am not coming!" As the boy leaves the training ground, the coach yells after him by calling his name: "ilyas, stop Illyas!" While ilyas runs away with anger and anxiety, one of the boys mocks him by shouting after him: "We will tell the pilot to fly low!" The next scene portrays a sequence in a village cottage while ilyas is sitting on the knees of an elderly woman, presumably a member of his family, and then sitting on the

3 In Turkey, male citizens are entitled with mandatory military service after the age of 18 . Military service is also culturally encoded as a threshold for becoming a "man" that reproduces hegemonic masculinity. Regarding the cultural dimensions of mandatory military service that is linked to the ideologies of nationalism and gender, see: Selek, 2014.

4 "Do not Give Up" advertisement was also published online in the following link: https://www. youtube.com/watch?v=2igGTfYsn-0 
lunch table with his family and listening to the news on television, while a young female reporter narrating: "Ordu-Giresun Airport, which is Europe's first airport constructed on the sea, is opened with the first Turkish Airlines flight." What follows is a series of attempts conducted by lilyas' family members and friends to relieve his stress about taking a flight so that he can prepare himself for the plane travel. The sequence of events unfolds with the scene which portrays Illyas lying on his bed, hopelessly and anxiously waiting, as the camera captures the Turkish national flag hanged on the wall above him. After this signifier of nationalism, the events progress and two children, including one male and one female, wake ilyas up for training. Accompanied with traditional music of Black Sea region, lilyas is surprised and still anxious, he doesn't know what they are doing and where he is heading. His friends stop by a long ladder and ask him to climb then taken to a high bridge to pass through, as ilyas rejects to perform both acts due to his phobia. The girl asks, "You have to perform if you want to be a goalkeeper", and gradually ilyas gets used to perform the actions in an abstentious manner, constantly asking "Won't I fall, will I?" and "Is this safe?" The consequent scenes include natural views from the Black Sea region, which is nationally known as possessing a rich environment with green areas, mountains and rivers. In the following scene, the team arrive at the airport, gets ready to enter the plane while ilyas arrives on the gates at the very last minute of the flight's departure time. He enters the plane and is celebrated by the passengers with joy. The narrator then intervenes and says the following: "Turkish Airlines; for Turkey, who does not know any obstacles to reach its dreams, to reach every corner of the country easily." In the very last scene after the narration, three elderly women are portrayed as working on the field, looking above the plane that passes by. One of the women whistles towards the plane, as the subtitles are provided as follows: "Do not give up son, do not give up."

The ending scene of the advertisement perfectly illustrates the kind of discourse that is established with regard to the Oriental subject vis-à-vis the Occidental authority. The way women stand below and whistle towards the plane situated on top while the advertisement speaks on their behalf is a clear manifestation of Spivak's (1988) emphasis on the non-speaking status of the subaltern being. Confronted with the supremacy of the center represented by Turkish Airlines, the peripheral women are deprived of any means to express themselves and the advertisement, as the hegemonic apparatus of the Western superiority, speaks in their place. Similarly, throughout the advertisement ilyas is represented as a passive and submissive being, who is unable to express himself other than the manifestation of emotions in a misappropriate way. Such like the first Turkish Airlines advertisement; the advertising discourse relies on interpellation of ilyas by the consumerist ideology of capitalism and the nationalist ideology of the nation-state. On his encounter with the center's Western superiority represented by the figure of the plane, ilyas demonstrates a particular form of subaltern resistance, that is, he refuses to take the plane and leaves his entire future career plans behind for that principal. The advertising 
discourse however portrays this subaltern resistance as a paranoid state of mind, provoked by the under-developed, less technological, irrational, less civilizational cultural setting that embodies his Oriental being. The discourse allegorically points out the Oriental subject as resisting change, technology and innovation, and reasserts its inferiority as opposed to the superior legacy of the West, namely, the Turkey's industrialized, modernized center.

As the sequence of events unfold, ilyas is surrounded by peripheral subjectivities, who already internalized the center's Occidental supremacy and who further seek to ease the process of his subjectification. In getting ilyas prepared to overcome his fear (or, subaltern resistance), what they actually eliminate is his resistance against Western superiority and to recreate him almost as a "docile body" (Foucault, 1995) that acknowledges and internalizes the exiting hierarchies of power. The appearance of the Turkish national flag hanged on the wall of 'llyas' bedroom that is followed by his friends' attempt to train him for the flight crucially marks the threshold which metaphorically signals his encounter with the ideology to which he is about to be exposed. The following events successfully provide ilyas with the necessary subjectivity that he can realize himself as a proper subject, both as a consumer who can enjoy the flight services, and as a citizen who participated to the national pride of what Turkish Airlines attempted by constructing Europe's only airport on the sea. The whole discourse is accompanied with the slogan "Do not give up", which exerts power on the peripheral other to fulfill his existence in line with nationalist and consumerist ideology of our contemporary society. Ilyas's subjectification is successfully completed upon his entrance to the plane, where the applause by passengers symbolically correspond to a celebration for his integration to the national whole as a proper subject both as a citizen and a consumer. Similar to the ways in which it is represented in the first Turkish Airlines advertisement, the peripheral other is portrayed as childish, anxious, frightened, weak, inconsistent and not wholly complete; an orientalist imagery that stands in contradistinction to the Western self, characterized with the wholeness, concreteness, strength and consistency of bodily and mentally state. The representation of the airport with utmost "modern" and "technological" signifiers is another discursive strategy that illustrates the Western supremacy over the East, which is incorporated as a crucial element in Turkish Airlines' brand image. Finally, as the advertisement describes the event as a "dream" that Turkey managed to actualize, advertising sets up a discourse of national and consumerist awakening for the peripheral other, who is once again rescued and enlightenment by Turkey's hegemonically established industrial, modern and national center.

\section{Conclusion}

As a field of power relations invested in representations, visual culture involves discourses of power, hegemony and ideology in various visual and textual mediums. Advertising is also considered as a powerful medium capable 
of constructing discourses and reproducing the hegemonic narratives inscribed in culture. Orientalism and colonial relations of power have been subjected to various representations in visual culture and advertising globally, either commodifying or naturalizing the hierarchies of power by narrativizing them to the audiences as consumers. With its unique stance in terms of colonial relations especially with regard to its internal dynamics divided between the center as the Western, modern, bureaucratic elite and the periphery as the Eastern, traditional, under-developed masses, Turkey provides crucial dynamics for different forms of orientalist discourses to operate and be invested in the language of visual culture and advertising in particular.

Turkish Airlines advertisements that were broadcast in the recent years perfectly illustrate the ways in which Oriental dichotomy has been inscribed in narrativizing center-periphery relations in Turkey. In this article, the critical discourse analysis of the advertisements aimed to show that the Oriental other, symbolically pointed out as peripheral provinces such as Iğdır, Ordu and Giresun, are subject to the hegemonic discourses of nationalist and consumerist ideology, which altogether facilitate the orientalist discourse. The peripheral subject is represented as underdeveloped, non-modern, less technological, emotional and childish whereas the Western supremacy at the center is represented as developed, modern, technological, rational, powerful and masculine. Nationalist and militarist narratives accompany the discourse in a way, which marks the subjectification of the citizen-in-the-making in accordance with the hegemonic narratives of the nation-state. Facilitating hierarchical power relations between the Western self and the peripheral other, the peripheral subject is discursively established within the advertising discourse as a proper individual-in-the-making; as his encounter with the center's industrial, technological and civilizational superiority aims to recreate him as an ideal national masculine subject and a potential consumer. In sum, as a technology of power in Foucauldian sense (1995), advertisements imagine the peripheral subject and produce generalized and stereotyped information from that imagination to let the agents of the center know about that subject, in order to practice their privileged identities as opposed to the distanced other. Eventually, the advertisements show that the brand aims to communicate its message for superiority, technological advancement, widespread network and the quality of its services with an orientalist discourse, by positioning itself as the superior Western agent, that tends to narrativize and imagine the Oriental subject with respect to power hierarchies ingrained in Turkey's center-periphery tensions. The brand applies this strategy to spread the orientalist dichotomy with advertising discourse and consequently to normalize the existing power relations between the center and the periphery so that they can be internalized by the peripheral subject who is expected to recognize the superiority of the brand as a citizen and appreciate its services as a consumer.

Strikingly, this particular discourse of othering has attracted the attention of urban middle-class audiences; as the children acting in Iğdır Airport 
advertisement were invited to "Beyaz Show", one of the most popular night talk-shows in Turkey's national television broadcasting. The encounter with the children, who were the representatives of the peripheral subjectivities, further facilitated a visual medium of power relations by which the supreme gaze of the urban middle-classes can be directed at the underdeveloped peripheral other, who is encoded as "exotic" and hence instrumentalized as an object of visual pleasure. Although the advertisements were met with wide interest in the eyes of the urban middle-class audiences, such representations that include stereotypes and generalizations regarding the status of individuals residing in Turkey's peripheral regions does not mean that individuals living in those regions accept such representations as they are. Contrarily, popular culture is a field where hegemonic meanings and discourses of power and ideology can be resisted and contested with an active agency, which may be the subject of another research to uncover the ways in which orientalist discourse is challenged or negotiated among different peripheral audiences.

\section{References}

Achebe, C. (1994). Things Fall Apart. New York: Anchor Books.

Aktar, A. (2008). "Turkification" Policies in the Early Republican Era. In C. Dufft (Ed.), Turkish Literature and Cultural Memory: "multiculturalism" as a Literary as a Literary Theme after 1980 (pp. 29-62). Wiesbaden: Harrassowitz Verlag.

Althusser, L. (2012). Ideology and Ideological State Apparatuses. In S. Zizek (Ed.), Mapping Ideology (pp. 100-140). London \& New York: Verso Books.

Appadurai, A. (1996). Modernity at large: Cultural dimensions of globalization. Minneapolis, MN: University of Minnesota.

Burke, E., and Prochaska, D. (2007). Rethinking the historical genealogy of orientalism. History and Anthropology, 18(2), 135-151.

Cagan, E. (1978). The selling of the women's movement. Social Policy (May/ June), 4-12.

Clark, D. (1991). Commodity lesbianism. Camera Obscura, 9(1-2 25-26), 181-201.

Cortese, A. J. (1999). Provocateur: Images of women and minorities in advertising. Lanham: Rowman \& Littlefield Publishers.

Erol, M. (2015). Greek Orthodox Music in Ottoman Istanbul: Nation and Community in the Era of Reform. Indiana: Indiana University Press.

Fanon, F. (1963). The Wretched of the Earth. New York: Grove Press.

Fanon, F. (1964). Toward the African Revolution. New York: Grove Press.

Foucault, M. (1978). The History of Sexuality: Volume 1 an Introduction. (R. Hurley, Trans.) New York: Pantheon Books. 
Foucault, M. (1995). Discipline and Punish: The Birth of the Prison. (A. Sheridan, Trans.) New York: Vintage Books.

Fowles, J. (1996). Advertising and Popular Culture. London: Sage.

Gill, R. (2009). Supersexualize me! Advertising and the Midriffs. In F. Atwood (Ed.), Mainstreaming Sex: The Sexualization of Western Culture (93-110). London \& New York: IB Tauris.

Goffman, E. (1976). Gender Advertisements. New York: Harper \& Row.

Goldman, R. (1992). Reading Ads Socially. London: Routledge.

Gramsci, A. (1971). Selections from the Prison Notebooks. New York: International Publishers.

Gürbilek, N. (1992). Vitrinde Yaşamak: 1980'lerin Kültürel Iklimi. İstanbul: Metis. Jhally, S. (1990). The Codes of Advertising: Fetishism and the Political Economy of Meaning in the Consumer Society. New York: Routledge.

Kim, M., and Chung, A. Y. (2005). Consuming Orientalism: Images of Asian/ American Women in Multicultural Advertising. Qualitative Sociology, 28(1), 6791.

Leiss, W., Kline, S., and Jhally, S. (1997). Social Communication in Advertising. London \& New York: Routledge.

Lin, M. (2008). The Representation of the Orient in Western Women Perfume Advertisements: A Semiotic Analysis. Intercultural Communication Studies, XVII(1), 44-53.

Mardin, Ş. (1973). Center-Periphery Relations: A Key to Turkish Politics? Daedalus, 102(1), 169-190.

McFall, L. (2004). Advertising: A Cultural Economy . London: Sage.

Modood, T. (2005). Multicultural Politics: Racism, Ethnicity, and Muslims in Britain. Minneapolis: University of Minnesota Press.

Mudambi, A. (2013). Another Look at Orientalism: (An)othering in Slumdog Millionaire. Howard Journal of Communications, 24(3), 275-292.

Nas, A. (2013). İslami Yaşam Tarzı ile Seküler İmgelem Arasında: Vodafone Katar ve Vodafone Türkiye Reklamlarında Ramazan Ayı Temsilinin Karşılaştırmalı Analizi. 2nd International Symposium on Language and Communication: Exploring novelties Book of Proceedings (1731-1742). İzmir: İzmir Üniversitesi.

Owens, P. (2010). Torture, Sex and Military Orientalism. Third World Quarterly, 31(7), 1041-1056.

Öncü, A. (1999). Istanbulites and Others: The cultural cosmology of being middle class in the era of globalism. In Ç. Keyder (Ed.), Istanbul: Between the Global and the Local (95-120). Maryland: Rowman \& Littlefield Publishers. 
Said, E. (1978). Orientalism. London: Penguin Books.

Said, E. (1997). Covering Islam: How the Media and the Experts Determine how We See the Rest of the World. New York: Vintage.

Selek, P. (2014). Sürüne Sürüne Erkek Olmak. İstanbul: İletişim Yayınları.

Spivak, G. C. (1988). Can the Subaltern Speak? In C. Nelson, \& L. Grossberg (Eds.), Marxism and the Interpretation of Culture (271-313). Chicago: University of Illinois Press.

Stokes, M. (1993). The Arabesk Debate: Music and Musicians in Modern Turkey. Oxford: Oxford University Press.

Turkish Airlines. (2014). The Rise Continues: Annual Report 2014. Retrieved January 20, 2016, from http://investor.turkishairlines.com/documents/ ThylnvestorRelations/download/yillik_raporlar/2014_Annual_Report_EN.pdf

van Dijk, T. (2001). Critical discourse analysis. In D. S. D. Tannen (Ed.), Handbook of discourse analysis (352-371). Oxford: Blackwell.

Williams, R. (1999). Advertising: The Magic System. In S. During (Ed.), The Cultural Studies Reader (410-423). London \& New York: Routledge.

Williamson, J. (1978). Decoding Advertisements: Ideology and Meaning in Advertising. London: Marion Boyars.

Williamson, J. (1986). Woman is an island: Femininity and colonization. In Studies in entertainment: Critical approaches to mass culture (99-118). Bloomington and Indianapolis: Indiana University Press.

Wright, A. (2005). The Work of Translation: Turkish Modernism and "the generation of 1914". In J. Hackforth-Jones, \& M. Roberts (Eds.), Edges of Empire: Orientalism and Visual Culture (139-161). Oxford: Blackwell.

Zeydanlığlu, W. (2008). The White Turkish Man's Burden: Orientalism, Kemalism and the Kurds in Turkey. In G. Rings, \& A. Ife (Eds.), Neo-colonial mentalities in contemporary Europe (155-174). Cambridge: Cambridge Scholars Publishing. 